\title{
Talon cusp in primary dentition: A case report
}

\author{
Ravi Prakash Sasankoti Mohan, Sankalp Verma, Udita Singh, \\ Neha Agarwal, Soumi Ghanta, Kuber Tyagi
}

\begin{abstract}
Introduction: Talon cusp is a well delineated accessory cusp projecting from the cingulum area of an anterior tooth. It is named so due to its resemblance with eagle's talon, which is the shape of eagle's claw when hooked on to its prey. Various alterations in shape in talon's cusp may be present like it may be either sharp or spiked, teat like or may have rounded and smooth tips. Only two cases have been reported in Indian population till date. Case Report: Hereby, we report a unique case of talon's cusp in a fouryear-old boy. Conclusion: The occurrence of talon's cusp in mandibular primary dentition is extremely rare.
\end{abstract}

Keywords: Cingulum, Accessory, Talon cusp

$* * * * * * * * *$

Ravi Prakash Sasankoti Mohan¹, Sankalp Verma², Udita Singh ${ }^{3}$, Neha Agarwal $^{3}$, Soumi Ghanta ${ }^{3}$, Kuber Tyagi ${ }^{4}$ Affiliations: ${ }^{1} \mathrm{MDS}$, Professor \& Head of the Department, Oral Medicine and Radiology, Kothiwal Dental College and Research Centre, Moradabad, Uttar Pradesh, India; ${ }^{2} \mathrm{MDS}$, Assistant Professor, Oral medicine and Radiology, Kothiwal Dental College and Research Centre, Moradabad, Uttar Pradesh, India; ${ }^{3}$ BDS, Post Graduate Student, Oral Medicine and Radiology, Kothiwal Dental College and Research Centre, Moradabad, Uttar Pradesh, India; ${ }^{4}$ MDS, Assistant Professor, Oral Medicine and Radiology, Teerthanker Dental College and Research Centre, Moradabad, Uttar Pradesh, India.

Corresponding Author: Dr. Ravi Prakash Sasankoti Mohan, C/o Dr. R. P. Singh (MS), Dhanwantri Nursing Home, Sarai Khalsa, Behind Head Post Office, Moradabad, Uttar Pradesh, INDIA. Pin-244001; Mob: 09997119919; Email: sasan_ravi@rediffmail.com

Received: 29 May 2013

Accepted: 11 July 2013

Published: 01 December 2013
Mohan RPS, Verma S, Singh U, Agarwal N, Ghanta S, Tyagi K. Talon cusp in primary dentition: A case report. International Journal of Case Reports and Images 2013;4(12):709-713.

$* * * * * * * * *$

doi:10.5348/ijcri-2013-12-417-CR-11

\section{INTRODUCTION}

Talon cusp is a rare dental anomaly, which originates during the morphodifferentiation stage of tooth development. It is defined as, "an additional cusp that predominantly projects from the lingual surface of primary or permanent anterior teeth, is morphologically well delineated and extends at least half the distance from cementoenamel junction to incisal edge" [1]. Although it affects both the primary and permanent dentition but permanent dentition is found to be involved thrice more commonly than the primary dentition. Several studies have reported a male and female ratio to be 2:1 $[2,3]$. Talon cusp is not entirely innocuous and may pose difficulties like predisposition to caries, occlusal interferences and unpleasant esthetics [4]. This article focusses on an extremely rare case presenting with talon cusp in mandibular primary dentition.

\section{CASE REPORT}

A four-year-old boy was reported to the outpatient department with a chief complaint of decaying of right lower back tooth region since 1-2 months. There was no remarkable medical or dental history. He was apparently healthy child born to non-consanguineous parents at full term. Nothing significant findings were elicited in general physical examination. Intraoral examination revealed mixed dentition with good oral hygiene. Dental caries was present in right lower back teeth (in relation to 73, 74). Apart from this, an 'extra cusp' was seen projecting from 
the lingual surface in relation to mandibular primary lateral incisor (72) as shown in Figure 1A. On close examination of the involved tooth (72), an accessory cusp was present, projecting from cingulum and involving more than half of the lingual surface (Figure 1B). Intraoral periapical radiograph confirmed the presence of talon cusp in relation to 72 (Figure 2). As talon cusp caused no difficulties to the patient, topical fluoride sealant was applied and patient was kept on follow-up at six monthly interval.

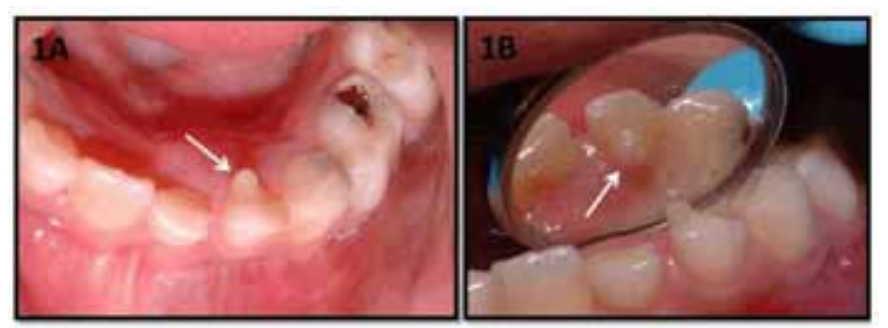

Figure 1: A 4-year-old boy presenting with talon's cusp in primary mandibular left lateral incisor: (A) Clinical photograph of intraoral view showing talon's cusp in relation to 72 . (B) Clinical photograph of intraoral view clearing showing talon cusp projecting from cingulum of 72 and extending to almost half the lingual surface.

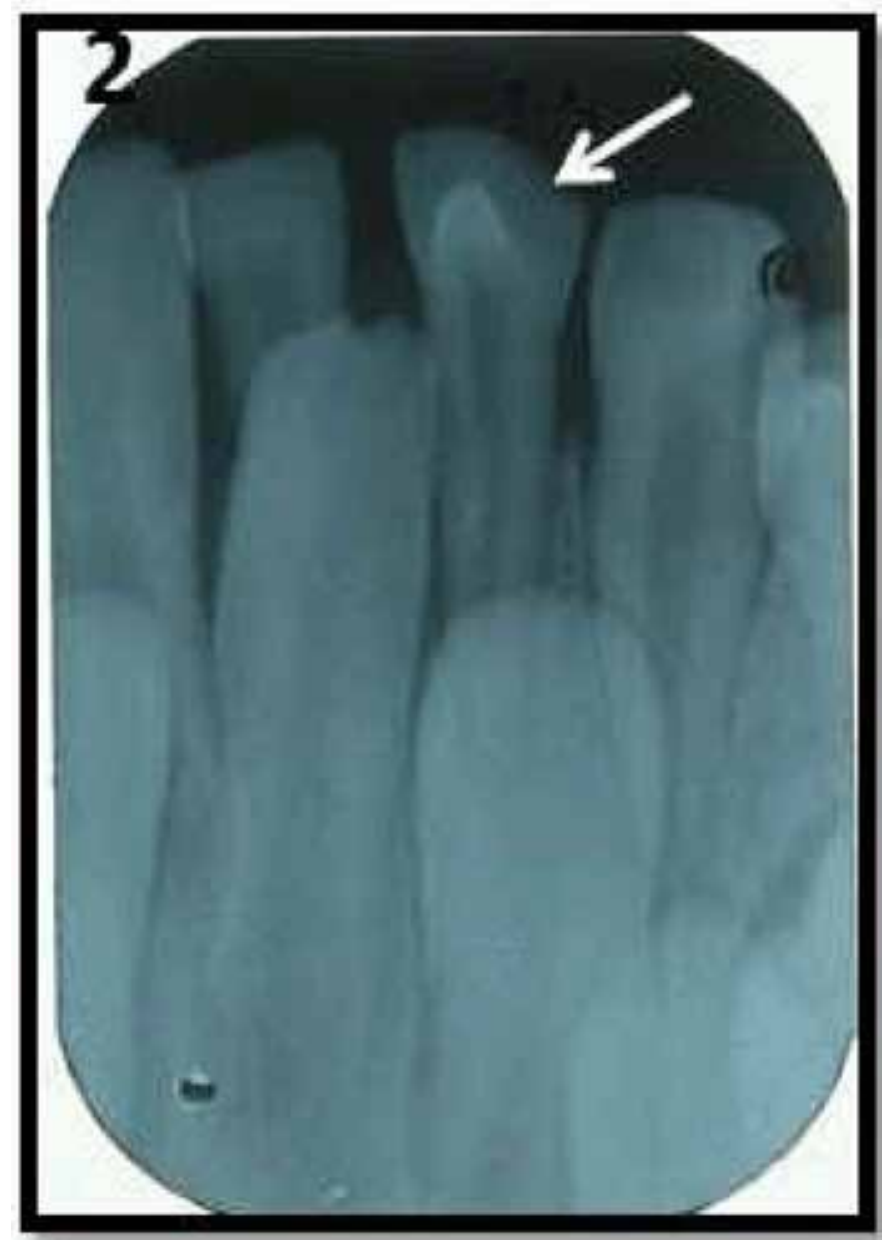

Figure 2: Intraoral periapical radiograph of mandibular anterior region confirming the presence of talon cusp in relation to 72 . Note that no involvement of permanent tooth buds was seen.

\section{DISCUSSION}

More than two centuries ago, William Mitchel described accessory cusp on the lingual surface of permanent upper central incisor of a woman and described it as, "process of horn like shape curving from the base downwards to the cutting edge". In 1972, Mellor and Ripa named it talon cusp owing to its close resemblance with an eagle's talon [3]. Since then , many names have been used for this dysmorphic disturbance of teeth, namely, dens evaginatus, supernumerary cusp, horn, hyperplastic cingulum, evaginated odontome, cusped cingulum, accessory cusp and supernumerary lingual tubercle [5]. The usage of multiple terms added up to confusion which was cleared when Mader suggested that the term talon cusp should be reserved only for those anomalous cusp that prominently projected from the lingual surface of a succedaneous tooth, that are morphologically well delineated and extend at least half the distance from cementoenamel junction to the incisal edge. Smaller cusp like projections in the cingulum should be referred to as enlarged or prominent cingulum [6].

The prevalence of talon cusp in primary dentition is extremely low as concluded from the review of literature from 1977 to 2013 (Table 1). Till date 34 cases of talon cusp in primary dentition have been reported from all over the world. Out of these 34 cases, only two are in the mandibular primary dentition and to the best of our knowledge, ours is the third reported case of this uncommon anomaly.

The etiology still remains unclear. Various hypotheses regarding its etiology have been put forward. Some of these are; it is supposed to be a consequence of outward folding of inner enamel epithelial cells or may be due to hyperactivity of dental lamina [2]. Another hypothesis suggests genetics to be a causativefactor of talon cuspbased on its occurrence in a family. Trauma and other localized forces on tooth germ have also been held responsible for talon cusp [2, 4, 10]. Lee proposed that hyperactivity of cells of tooth germ may lead to development of talon cusp, which is genetically determined but the degree is influenced by environmental factors [16].

Clinically, it presents as an accessory cusp that projects from the cingulum area of anterior teeth and involves more than the half of the lingual or palatal surface. Hattab et al. classified talon's cusp based on the degree of formation and extension into three categories. These are [15]:

- Type 1 (True talon): A well-delineated additional cusp that predominantly projects from the palatal or lingual surface of an anterior teeth and extends half way from cementoenamel junction to the incisal edge (as seen in our patient).

- Type 2 (Semi talon): An additional cusp of a millimetre or more but extending less than half the distance from cementoenamel junction to incisal edge. It may blend with palatal surface or strand away from the crown 
Table 1: The prevalence of talon cusp in primary dentition from 1977 to 2013.Till date 34 cases of talon's cusp in primary dentition have been reported from all over the world. Out of these 34 cases, only two are in the mandibular primary dentition and to the best of our knowledge, ours is the third reported case of this uncommon anomaly

\begin{tabular}{|c|c|c|c|c|c|c|}
\hline S. No & Name of Author & Year & $\begin{array}{l}\text { Maxillary } \\
\text { Dentition }\end{array}$ & $\begin{array}{l}\text { Mandibualr } \\
\text { Dentition }\end{array}$ & Age of Patient & \\
\hline 1 & S.K. Mallineni et al. ${ }^{[7]}$ & 2013 & 51 & - & $\begin{array}{l}4 \text { year+ } 2 \text { months } \\
\text { Female }\end{array}$ & Chinese \\
\hline 2 & S.K.Mallineni et al. ${ }^{[7]}$ & 2013 & 51 & - & $\begin{array}{l}2 \text { year }+9 \text { months } \\
\text { Male }\end{array}$ & , \\
\hline 3 & , & , & 61 & - & $\begin{array}{l}2 \text { year +9 months } \\
\text { Male }\end{array}$ & ", \\
\hline 4 & Prabhu et al. ${ }^{[8]}$ & 2012 & 62 & - & 4 years Male & South Indian \\
\hline 5 & $\begin{array}{l}\text { Swaminathan Kavitha } \\
\text { et al. }{ }^{[9]}\end{array}$ & 2012 & - & 82 & 5 years Male & , \\
\hline 6 & S.Hedge et al..$^{[10]}$ & 2011 & - & 72 & Not available & , \\
\hline 7 & Praveen P et al. ${ }^{[11]}$ & 2011 & 51 & - & 8 years Male & , \\
\hline 8 & A.Kapur et al. ${ }^{[12]}$ & 2011 & 51 & - & 4 years male & , \\
\hline 9 & Chun Kei Lee et al. ${ }^{[13]}$ & 2008 & 52 & - & & Chinese \\
\hline 10 & ", & ", & 52 & - & & , \\
\hline 11 & , &, & 52 & - & & , \\
\hline 12 & Yoon RK \& Chussid $S^{[14]}$ & 2006 & 51 & - & 14 months Male & New York \\
\hline 13 & Tsaii AL \& Chang $\mathrm{P}^{[14]}$ & 2003 & 51 & - & 13 months Female & Chinese \\
\hline 14 & Gungor $\mathrm{H}$ et al. ${ }^{[14]}$ & 2000 & 51 & - & 14 months Male & , \\
\hline 15 & $\begin{array}{l}\text { Hattab FN \& Yasin } \\
\mathrm{OM}^{[14]}\end{array}$ & 1996 & 51 & - & 17 months Male & " \\
\hline 16 & Seadano et al. ${ }^{[15]}$ & 1989 & \multicolumn{3}{|c|}{ Prevalence of talon cusp in primary dentition $=0.06 \%$} & Mexican \\
\hline 17 & Chawla et al. ${ }^{[15]}$ & 1983 & \multicolumn{3}{|c|}{ Prevalence of talon cusp in primary dentition $=7.7 \%$} & North Indian \\
\hline 18 & Liu JF \&Chen JR ${ }^{[14]}$ & 1955 & 51 & - & $\begin{array}{l}12 \text { months } \\
\text { Female }\end{array}$ & Chinese \\
\hline 19 & , & , & 51 & - & , & Chinese \\
\hline 20 & , & , & 51 & - & $\begin{array}{l}3 \text { years+6 months } \\
\text { Female }\end{array}$ & Chinese \\
\hline 21 & , & , & 51 & - & $"$ & Chinese \\
\hline 22 & Meon R et al. ${ }^{[14]}$ & 1990 & 51 & - & 4 years Male & , \\
\hline 23 & Morin CK et al. ${ }^{[14]}$ & 1987 & 51 & - & 12 months Male & ", \\
\hline 24 & Chen RJ \& Chen HS ${ }^{[14]}$ & 1986 & 51 & - & 10 months Male & " \\
\hline 25 & , & , & 51 & - & 6.5 years & " \\
\hline 26 & , &, & 51 & - & 9 months Male & , \\
\hline 27 & , & $\begin{array}{l}\text { Not } \\
\text { available }\end{array}$ & 51 & - & 13 months Male & , \\
\hline 28 & , & ", & 51 & - & 4 years Male & , \\
\hline 29 & , & ", & 51 & - & 6 years Male & , \\
\hline 30 & $\begin{array}{l}\text { Davis } \\
\mathrm{AH}^{[1,14]}\end{array} \quad$ PJ \&Brooke & 1986 & 51 & - & 5 years Male & - \\
\hline 31 & , & ", & 51 & - & 5 years Male & - \\
\hline 32 & Natkin $E^{[14]}$ & 1983 & 51 & - & 5 years Male & - \\
\hline 33 & Mass et al. ${ }^{[14]}$ & 1978 & 51 & - & 1 year Male & - \\
\hline 34 & Henderston $\mathrm{HZ}$ et al. ${ }^{[14]}$ & 1977 & 51 & - & 4 years Female & - \\
\hline
\end{tabular}


- $\quad$ Type 3 (Trace Talon): Enlarged cingulum and may present as conical bifid or tubercle shaped.

Histologically, it may or may not contain pulpal tissue. Radiographically, it appears to be superimposed over the tooth on which it develops [4]. Talon cusp may be seen in association with Mohr syndrome, Rubinstein-Taybi syndrome, Sturge-Weber syndrome, Ellis-van Creveld syndrome [7].

The clinical problems associated with talon cusp are predisposition to caries due to the presence of deep grooves and resultant stagnation of food debris, periapical lesions, occlusal interference, and irritation to tongue during mastication or speech. But our patient presented with no difficulties.

Treatment is required only for symptomatic cases. In case of deep developmental grooves, these should be thoroughly cleaned to get rid of debris and sealed using fissure sealant. In case of carious grooves, restoration of the involved tooth becomes mandatory. If due to deep carious lesion or occlusal interferences, a portion of talon cusp has to be removed then grinding should be done gradually on consecutive visits at six weeks intervals so as to ensure deposition of reparative dentin. Pulp therapy is done in cases of pulpal involvement $[7,8,11]$.

\section{CONCLUSION}

In this article, we have reviewed literature regarding talon cusp in primary dentition and have added significantly to the present knowledge by documenting a rare case report.

$* * * * * * * * *$

\section{Author Contributions}

Ravi Prakash Sasankoti Mohan - Substantial contributions to conception and design, Acquisition of data, Analysis and interpretation of data, Drafting the article, Revising it critically for important intellectual content, Final approval of the version to be published Sankalp Verma, Udita Singh - Substantial contributions to conception and design, Acquisition of data, Analysis and interpretation of data, Revising it critically for important intellectual content, Final approval of the version to be published

Neha Agarwal - Substantial contributions to conception and design, Acquisition of data, Analysis and interpretation of data, Revising it critically for important intellectual content, Final approval of the version to be published

Soumi Ghanta - Substantial contributions to conception and design, Acquisition of data, Analysis and interpretation of data, Revising it critically for important intellectual content, Final approval of the version to be published

Kuber Tyagi - Substantial contributions to conception and design, Acquisition of data, Analysis and interpretation of data, Revising it critically for important intellectual content, Final approval of the version to be published

\section{Guarantor}

The corresponding author is the guarantor of submission.

\section{Conflict of Interest}

Authors declare no conflict of interest.

\section{Copyright}

(C) Ravi Prakash Sasankoti Mohan et al. 2013; This article is distributed under the terms of Creative Commons attribution 3.0 License which permits unrestricted use, distribution and reproduction in any means provided the original authors and original publisher are properly credited. (Please see www.ijcasereportsandimages.com/ copyright-policy.php for more information.)

\section{REFERENCES}

1. Davis PJ, Brook AH. The presentation of talon cusp: Diagnosis, clinical features, association and possible aetiology. British Dental Journal 1986 Feb 8;160(3):84-8.

2. Shafer WG, Hine MK, LevyBM. A textbook of oral pathology. 4th ed. Philadelphia: WB Saunders 1983:40-1.

3. Mellor JK, Ripa LW. Talon cusp: A clinically significant anomaly. Oral Surg Oral Med Oral Pathol 1970 Feb;29(2):225-8.

4. Goaz PW, White SC. Oral Radiology. Missouri: CV. Mosby Company 1987;2:447.

5. Gardener DG, Girgs SS. Talon cusps: A dental anomaly in the Rubinstein-Taybi syndrome. Oral Surg Oral Med Oral Pathol 1979 Jun;47(6):519-21.

6. Marder CL. Talon Cusp. J Am Dent Assoc 1981 Aug;103(2):244-6.

7. Mallineni SK, Manan NM, Lee CK, King NM. Talon cusp affecting primary dentition in two siblings: A case report. Rom J Morphol Embryol 2013;54(1):2113 .

8. Rachana V Prabhu, Prasanna Kumar Rao, Veena KM, Prathima Shetty, Laxmikanth Chatra, Prashanth Shenai. Prevalence of Talon cusp in Indian population. J Clin Exp Dent2012;4(1):e23-7.

9. Swaminathan Kavitha, Haridoss Selvakumar, Rajendran Barathan. Mandibular talon cusp in primary lateral incisor: A rare case report. Case Rep Dent 2012;2012:670745.

10. Hedge S, Ashok Kumar BR. Mandibular talon cusp: Report of 2 cases. Int Journal of Paediatric dentistry 2004;9(4):303.

11. Praveen P, Anantharaj A, Karthik Venkataraghavan, Prathibha Rani, Jaya AR. Talon Cusp In A Primary Tooth. Journal of dental science and research 2011;2(1):35-40.

12. Kapur A, Goyal A, Bhatia S. Talon cusp in a primary incisor: A rare entity. Journal of Indian society of Pedodontics and Preventive dentistry 2011 JulSep;29(3):248-50. 
13. Chun-Kei Lee, Nigel M King, Edward CM L, Shiuyin Cho. Talon cusp in primary dentition-literature review and report of 3 cases. Journal of clinical pediatric dentistry 2008;30(4):153-6.

14. Yoon RK, Chussid S. Dental management of a talon cusp on a primary incisor. Pediatric dentistry 2007 Jan-Feb;29(1):51-5.

15. Hattab FN, Yassin OM, Al-Nimri KS. Talon cusp in permanent dentition associated with other dental anomalies: Review of literature and report of 7 cases. ASDC J Dent Child 1996 Sep-Oct;63(5):368-76.

16. Lee CK, King NM, Lo EC, Cho SY. Talon cusp in the primary dentition: Literature review and report of three rare cases. J Clin Pediatr Dent 2006;30(4):299305.
Access full text article on other devices

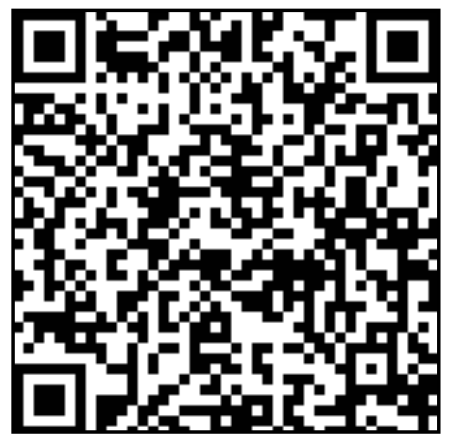

Access PDF of article on other devices

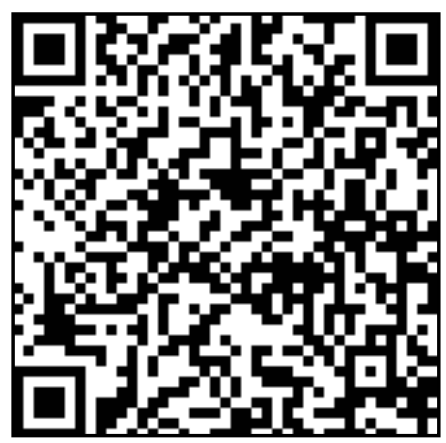

